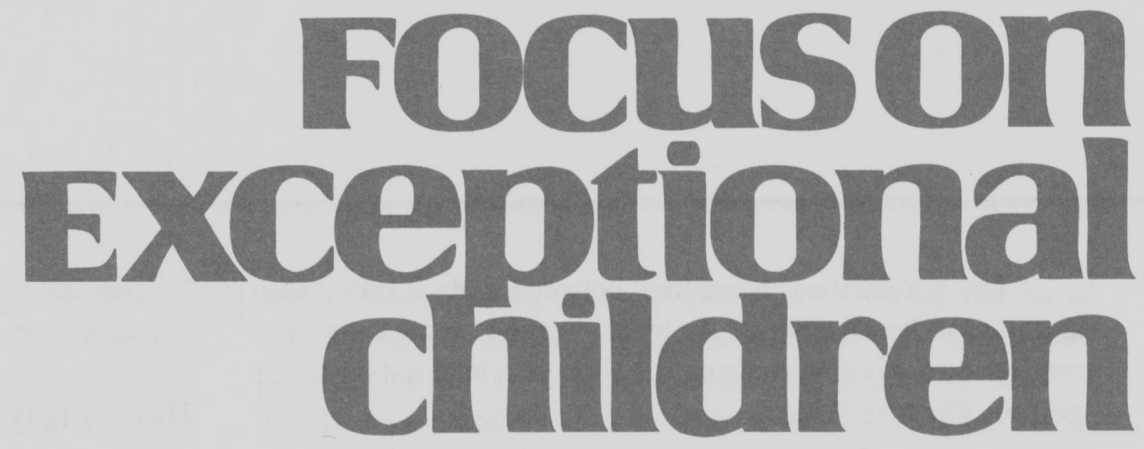

\title{
Early Intervention and Secondary/Transition Services: Harbingers of Change in Education
}

\section{P. Jeannie Kleinhammer-Tramill, Sharon E. Rosenkoetter, and James L. Tramill}

Clues to the future of the rapidly changing field of special education may be glimpsed in the supposedly disparate services of early intervention and secondary/transition to adulthood. Upon examination, early intervention for infants and toddlers with special needs and their families and future-oriented services for adolescents and young adults with disabilities share striking similarities. Recognition of the congruity between structures at these two levels is essential to effective local systems planning for individuals with developmental delays and disabilities. In addition, recognition of effective practices for service provision at one level can inform and empower practitioners across the service system. At both levels the organizational structures prompted by PL 101-476, the Individuals with Disabilities Education Act (IDEA, 1990, 1991), and emerging definitions of recommended practices help to provide the conceptual foundation for a new model for integrated, uninterrupted services to persons with special needs at all ages.

The significant departures in organization and practice at the early intervention and secondary/transition levels challenge traditional special education systems and, as a result, require dramatic rethinking in personnel preparation. In this article we explore similarities across these two age levels, describe differences in services at each level, recommend actions to improve the coordination of developmentally appropriate services across the life span for individuals with disabilities and their families, and address the implications of these issues for providers of personnel development and services to consumers.

The commonality of approaches to persons with special needs in infancy and adolescence is rooted in the organizational structures defined by federal law. Through interagency collaboration, these organizational structures are designed to be: (a) horizontally administered, (b) consumer-driven, and (c) community-referenced. At both levels effective services are likely to be articulated through local coordinating councils and by personnel carrying out the service coordination functions mandated by federal and state policies, and at both levels the potential exists for full-scale service integration.

Jeannie Kleinhammer-Tramill is an associate scientist with the University Affiliated Program, University of Kansas. Sharon Rosenkoetter is an associate professor in the Department of Special Education, Associated Colleges of Central Kansas, McPherson. James Tramill is a measurement and evaluation specialist in the Department of Planning and Evaluation, Topeka Public Schools. 
The similarities in practice between early intervention and secondary/transitional level special education are grounded in several concepts basic to services for both age groups. These include:

- a commitment to developmental appropriateness in service delivery

—defined procedures for transition planning

-expanded definitions of "education"

- provision of services in natural environments

The paragraphs that follow provide an overview of specific similarities in structures and practices impacting infants, toddlers, adolescents, and young adults with developmental delay or disability.

\section{SIMILARITIES IN ORGANIZATION OF SERVICES}

To be effective, intervention at both levels must be

\section{FOcus on
Exceptional
children}

ISSN 0015-511X Focus on Exceptional Children (USPS 203-360) is published monthly except June, July, and August as a service to teachers, special educators, curriculum specialists, administrators and those concerned with the special education of exceptional children. This publication is annotated and indexed by the ERIC Clearinghouse on Handicapped and Gifted Children for publication in the monthly Current Index to Journals in Education (CIJE) and the quarterly index, Exceptional Children Education Resources (ECER). It is also available in microfilm from University Microfilms International, Ann Arbor, MI 48196. Subscription rates: individual, \$30 per year; institutions, $\$ 40$ per year. Copyright (C) 1994, Love Publishing Company. All rights reserved. Reproduction in whole or part without written permission is prohibited. Printed in the United States of America. Second class postage is paid at Denver, CO. POSTMASTER: Send address changes to:

Love Publishing Company

Executive and Editorial Office

1777 S Bellaire Street

Denver, CO 80222

Telephone: 303-757-2579

EDITORIAL BOARD

Edward L. Meyen
University of Kansas

Glenn A. Vergason Georgia State University

Richard J. Whelan

University of Kansas Medical Center

Stanley F. Love

Publisher horizontally administered, community-referenced, and consumer-driven. These concepts are discussed next.

\section{Horizontally Administered Services}

Early intervention and secondary/transition to adulthood services alike are organized to encourage horizontal decision making across a variety of agencies and by consumers working in collaboration with service providers. At the early intervention level, Part H of PL 99-457 was crafted to establish the purposes and broad parameters for intervention but to allow individual states to determine their own structures and funding patterns for comprehensive services to infants and toddlers with special needs and their families (Ballard, Ramirez, \& Zantal-Wiener, 1987). Part $\mathrm{H}$ also allowed states to define which children and families are eligible to receive its services (Trohanis, 1989). States responded with a variety of lead agencies, interagency commitments, eligibility formulas, and patterns of service delivery (OSEP, 1993).

Although Part $\mathrm{H}$ structures differ dramatically from place to place, every state and territory requires multiagency participation in decision making. The legislation clearly intended to create horizontal structures within states to encourage interagency system development to meet the diverse needs of infants, toddlers, and their families (Sugarman, 1991). Within each state, agencies with histories of limited collaboration and often extensive competition for funds have been compelled to work together to create and implement services for infants and toddlers and their families.

Even though legal imperatives for interagency collaboration may result in little more than a system for handing off responsibilities from one agency to another, at best they promote blending of funds and coordination of services to meet consumer needs efficiently. Typically, the state pattern is replicated to a greater or lesser degree in interagency efforts at the local level (OSEP, 1993). Without question the multiagency involvement, shared decision making, and broad-based, comprehensive intervention services for babies and their families expand upon traditional notions of schooling (Hanson \& Lynch, 1989; Raver, 1991).

Horizontal decision making in the form of interagency cooperation has been written into several pieces of legislation, including PL 98-524 (the Carl Perkins Vocational Education Act), PL 99-506 (the Rehabilitation Act Amendments of 1986), and PL 101-467, all of which affect adolescents and young adults with disabilities. These im- 
peratives emerged in response to abundant evidence that existing educational services for adolescents and young adults were ineffective in producing desired employment and community participation outcomes (Benz \& Halpern, 1987; Edgar, 1987; Kiernan \& Ciborowski, 1986; Wehman, 1992).

In addition to legislation, interagency agreements at the federal level provided models for state interagency agreements (Schalock, 1985), acknowledging that adolescents with disabilities and their families may need support from a variety of sources: secondary educators, employers, vocational rehabilitation counselors, adult services agencies, social services, lawyers, financial counselors, and public or private postsecondary educators (Turnbull, Turnbull, Bronicki, Summers, \& Roeder-Gordon, 1989).

As decisions are made simultaneously across agencies and as adolescents with disabilities are prepared for employment and independent living, education no longer exists in the hierarchical format through which it has been defined customarily. Successful adolescent services depend on the development of new horizontal structures involving business, health, social service, education partnerships, and role interchanges (Johnson, Bruininks, \& Thurlow, 1987).

These horizontal structures for making decisions at the prekindergarten and secondary levels are significant beyond their impact on individual students and their families because horizontal decision making promotes systems change. Kanter (1983) determined that complex, interdependent organizational units and uncertain organizational mandates stimulate innovation. In pursuing new options for services, Weick $(1976,1979)$ recommended affirmation of organizational change and equivocality, as opposed to traditional bureaucratic standards of efficiency and standardization. Skrtic (1991) argued that bureaucracies function to stifle innovation, whereas adhocracies (horizontal systems for decision making) operate as tools of change. Interagency collaboration functions to expand recognition of the variety of services existing for the target populations, to bring attention to new areas of need, and to foster the development of strategies for realizing a full array of services for infants, toddlers, adolescents, and young adults at both state and local levels.

\section{Community-Referenced Services}

Effective systems at the local level are those that can address individual needs in a timely manner and provide families with easy access to all services within the system through a single point of contact (Halpern, Benz, \& Lind- strom, 1991; Hobbs et al., 1984). One of the hallmarks of current reform movements in education, health, and human services is the emphasis on local initiatives to identify needs, locate and develop resources, eliminate redundancy, and allocate personnel and funds to meet the needs of local citizens (Kagan, 1991; Melaville \& Blank, 1993; National Association of State Boards of Education, 1991). The goals of these efforts is to provide continuous services appropriate to the culture and resources of the specific community as well as appropriate to the diverse needs of individuals.

Across the nation local coordinating councils are required under Part $\mathrm{H}$ systems of many states, and local transition councils likewise are required by several states and prompted by generally accepted transition quality indicators (cf. Bates, 1990). These local councils, organized to coordinate services at each age level, are becoming the stimulus for achieving community-responsive, locally appropriate services at the infant/toddler and adolescent/young adult age levels (Halpern et al., 1991; Hazel et al., 1988; Johnson et al., 1987; Swan \& Morgan, 1993; Wehman, 1992).

From a systems perspective the two types of councils are similar for babies and adolescents, both in their membership lists and in the informal relationships and formal written agreements that result. Effective collaboration among community groups holds the potential for stimulating a system of seamless services for people at all ages who have special needs (Melaville \& Blank, 1993). For schools, participation in efforts such as these provides a new role (Johnson et al., 1987; Kagan, 1991) that is important for achieving positive outcomes for students and their families.

Local coordinating councils may serve a purely advisory, problem-solving role. In contrast, some states have chosen to channel funds directly to their local councils; in this event councils may maintain separate funding streams for a variety of programs to benefit children and their families (Sugarman, 1991), or they may blur categories and mesh funds to meet identified needs (Hardman \& McDonnell, 1987; Sugarman, 1991). Obviously the extent of collaboration affects the amount of system change accomplished.

\section{Consumer-Driven Services}

In early childhood and in adolescence alike, programs for students must be crafted individually to provide services across agencies. In both cases the range of options, including traditional classroom services and community placements, is likely to be extensive. 
The stakes are high for children and youth. Evidence shows that the location of service delivery for children in early intervention and preschool foreshadows the degree of restrictiveness of later placements (Miller, Strain, McKinley, Heckathorn, \& Miller, 1993). Similarly, for adolescents with disabilities, the degree of success in transitional planning and intervention largely determines the extent to which the young adult achieves social and financial independence (Chadsey-Rusch, Rusch, \& O'Reilly, 1991; Kohler, 1993). These factors are important not only for the student but also for that individual's entire family system.

Turnbull, Bateman, and Turnbull (1993) have pointed out that both the IDEA and PL 101-336, the Americans with Disabilities Act (ADA), speak to family empowerment in serving people of all ages with disabilities. The need for family empowerment seems especially noteworthy within early childhood and secondary-level services.

During the early years family members are the primary caregivers for the child. Simeonsson and Bailey (1990) suggested that this function leads to two different roles for family members in early intervention: as participant in delivering the intervention and as client or recipient of services. Both roles support the consumer-driven nature of early intervention. Historically, parents have functioned as co-therapists or co-teachers (intervention participant role) in early services. Highly divergent cultural values about where and how infants and young children should be socialized require that service systems be responsive to families' values, preferences, and needs (Lynch \& Hanson, 1992).

The Individuals with Disabilities Education Act developed the client role for families in early intervention when it mandated that planning and intervention occur with a family focus rather than a child focus. Thus, an individual family service plan (IFSP), rather than an individualized education program (IEP), is written for children at ages birth through 3 or 5 , depending upon state, local, and parent preference (McGonigel, Kaufmann, \& Johnson, 1991). Recommended practices in early childhood intervention feature family empowerment as a primary intervention goal (Division for Early Childhood, 1993; Dunst, Trivette, \& Deal, 1988). One rationale is that supporting families in learning to negotiate the maze of service providers when their child is young will provide continuing strategies for advocacy as the child matures. It also will ease stress for service providers if families are partners in decision making and subsequently work together with providers to implement the decisions that have been made cooperatively (Rosenkoetter, Hains, \& Fowler, 1994).
Self-determination by the student plays a much greater role in adolescence than it does in early childhood. Typically, adolescents develop greater autonomy from their parents as they age. Careful planning and intense intervention, however, may be necessary to help a student learn to live in the community, work outside the home, and make personal choices. During adolescence and young adulthood the student and his or her family are called upon to consider issues with lifelong impact. Partnership of service providers with families during this process drives interventions in directions that are most likely to accomplish the family's and young adult's goals (Brotherson, Berdine, \& Sartini, 1993; Turnbull et al., 1993).

Johnson, Bruininks, and Thurlow (1987) summarized the broad scope of family responsibility in planning for the adolescent or young adult with disabilities when they stated:

The family is the primary entity that must maintain constant supervision of an adult son's or daughter's needs for continued and ongoing services. The participation of families in planning during their children's adolescent years is essential for ensuring continuity between school and adult services. (p. 524)

Indeed, families of adolescents with disabilities face tremendous responsibilities in learning to negotiate the broad array of adult services, bridge potential gaps in services, and plan for the financial security of their son or daughter (cf. Turnbull et al., 1989).

Even though the literature on secondary transition consistently emphasizes the need for family participation in planning for adolescents and young adults, Lynch and Stein (1982) found that families of adolescents participate less often in IEP meetings than do families of younger children. Given the challenges that families face in coping with new configurations of services for their adolescent child, planning for his or her financial security, determining the locus of decision-making responsibilities, and supporting the young adult's progressive independence (Turnbull et al., 1993), families would seem to benefit from the same enfranchisement as clients that is implied by the IFSP during the early childhood years.

Because planning and intervention at both early childhood and secondary levels encompass activities in a range of venues and because so many different agencies and options have to be considered, community service systems must be responsive to the lifestyles, values, and preferences of family members as well as those of the infant, toddler, adolescent, or young adult. 


\section{Service Coordination}

Traditionally schools provide education and educationally related services to students with disabilities but are not required to monitor or coordinate any other services that the student or the student's family may receive. At the two age levels under discussion in this article, however, states are required by law to provide service coordination. Service coordination, often called case management, is a critical tool in planning for the diversity of services to individual children and adolescents and their families. Bailey (1989) and Agosta (1989) noted the important but challenging task of defining roles of service coordinators in delivering services at the secondary/transition and early intervention levels, respectively. At each level the array of individuals who might provide service coordination, the need for flexibility in designating case management responsibilities as the student matures, and the urgent need for training service coordinators are comparable (Zipper, Hinton, Weil, \& Rounds, 1993; Agosta, 1989).

\section{School-Linked Service Integration}

The promise of the horizontally administered, consumer-driven, and community-referenced structures for early intervention and secondary/transition to adulthood services lies in the potential for these services to exist within the context of full-scale, school-linked service integration, wherein a comprehensive array of services is "wrapped around" each child or adolescent and his or her family (Kirst \& McLaughlin, 1990; Sailor, 1991; Sailor et al., 1989). School-linked service integration would establish the school, broadly defined, as the single point of contact and coordinating vehicle for health services, social welfare services, mental health services, adult services, employment services, and legal assistance, configured according to the needs of individual families and driven by family services plans (Sailor, 1991; Sailor, Gerry, \& Wilson, 1993).

Although some local and state efforts fall short of realizing this promise (e.g., U.S. General Accounting Office, 1992), the description of similarities in practice, provided in the paragraphs that follow, underscores the need for coordinated and integrated services to children and adolescents as they enter and leave the educational system. Moreover, the organizational structures defining early intervention and secondary/transition to adulthood may serve as heurisitics for future service systems for individuals with special needs across the age span.

\section{SIMILARITIES IN PRACTICE}

Similarities in practice between early intervention and secondary/transition level special education services are, as evidenced in the previous sections, closely tied to similarities in structure. We have identified the elements of developmentally appropriate practice at both age ranges, transition planning, the need for expanded definitions of education, and selection of natural environments as sites for service delivery as core similarities in practice. We believe that the principles underlying each of these issues in practice must guide families, early interventionists, educators, and interagency council members as they plan, deliver, and evaluate services for babies and adolescents and their families.

\section{Developmentally Appropriate Practice}

Bredekamp (1987) publicized the term developmentally appropriate practice in the context of urging early childhood educators to address the developmental needs of young children rather than initiating children into academics at younger and younger ages. Developmentally appropriate practice honors the concept of diversity of performance levels within groups of children. It has two inherent concepts: (a) age appropriateness, which is similar to normalization of early childhood curricula (Wolfensberger, 1972), and (b) individual appropriateness, which involves curricular adaptations to meet individual needs. Historically, Bredekamp's admonition came just at the time that early childhood special education and early intervention services were emerging under the auspices of PL 99-457, and it continues to shape the development of the young field of early childhood intervention.

The concept of developmentally appropriate practice for children with special needs becomes controversial in the context of this question: How active should adults be in intervening to change the natural developmental course of a child with disabilities? Conversely stated by Goodman (1992), how much should adults "just let kids be kids?" Bricker and Cripe (1992) and Widerstrom (1991) argued that developmentally appropriate practice and intervention can be combined easily and effectively if significant adults follow the child's lead and take advantage of intervention opportunities provided by materials, routines, and play activities the child chooses.

At a time when young children with special needs are increasingly included in community child care and preschool programs (Peck, Odom, \& Bricker, 1993), the concept of developmentally appropriate practice is a significant 
standard in the choice of instructional strategies, selection of materials and media for young children, and pursuit of ways to deliver least intrusive interventions within least restrictive environments (Bredekamp \& Rosegrant, 1992). Though early childhood educators may disagree about the nature of intervention strategies (Carta, Schwartz, Atwater, \& McConnell, 1991; Mahoney, Robinson, \& Powell, 1992), most interventionists, nevertheless, relate to the child, first as a young child. They employ materials that are interesting for young children, provide services in locations and through systems appropriate to typically developing young children, and embed intervention activities within activities chosen by the children rather than by their teacher (Wolery, Strain, \& Bailey, 1992). Significantly, in a developmentally appropriate program, diversity is celebrated rather than discouraged (NAEYC \& NAECS/SDE, 1992).

Similarly, the term developmentally appropriate practice may be applicable in describing special education services at the secondary/transition to adulthood level if used to mean the selection of instructional strategies, curricula, and instructional settings that are developmentally appropriate for adolescents or young adults and that promote self-determination by the student. If so used, the term must be differentiated, of course, from so-called developmental approaches that involved following normative developmental order and hierarchies in teaching skills regardless of their functional appropriateness or of the student's age (Brown et al., 1979).

Although the term developmentally appropriate practice has not been applied previously with students at the secondary, postsecondary, or adult service levels, professionals have recognized for almost two decades that the educational needs of adolescents are different from those of elementary school children (cf. Alley \& Deshler, 1979; Brown et al., 1979; D’Alazo \& Wiseman, 1978; Zigmond, Silverman, \& Laurie, 1978). In 1979 Alley and Deshler reported that secondary special education programs for students with mild disabilities often were identical to elementary school programs in terms of instructional objectives, teaching methods, and materials. Widespread recognition that these practices were socially and educationally inappropriate, together with the recognition that young adults with disabilities often failed to achieve satisfactory outcomes in terms of employment and community participation, launched the "transition movement" of the 1980s (cf. Will, 1984). Even though different models for serving adolescents and young adults with disabilities place varying emphasis on secondary, postsecondary, or adult services, recommended practices now recognize the need for curricu- lar and instructional approaches that take into account the developmental needs of adolescents and young adults.

Recommended curriculum areas include academic content (including learning strategies), employability content (including exposure to a continuum of levels of support in employment as well as to a variety of jobs), and social content (including specific instruction in employmentrelated social skills, self-advocacy, self-determination, and leisure, recreational, and friendship-related social skills) (e.g., Bates, 1990; Deshler \& Schumaker, 1986; Edgar, 1987; Halpern, 1987; Hardman \& McDonnell, 1987; Kokaska \& Brolin, 1983; Mithaug, Martin, \& Agran, 1987; Rojewski, 1992). Recommended instructional approaches and settings include continued integration into mainstream educational settings together with community-based instruction to promote acquisition and application of skills in natural environments (e.g., Clark \& Kolstoe, 1990; Edgar, 1987; Sailor et al., 1989; Turnbull et al., 1993). As evidenced in the discussion to follow, the need for developmentally appropriate practice also is seen in instructional management tasks such as assessment and transition planning.

Recent evidence (Clark \& Mellard, 1992) suggested that a gap remains between recommended and actual practice in secondary school special education in spite of the impetus for change from legislation and model program initiatives. Secondary-age students still are being taught with methods and materials more suitable for younger children. Thus, the concept of developmentally appropriate practice seems to merit special attention from administrators seeking to improve services for adolescents and young adults with disabilities.

A continuing challenge at early childhood and secondary levels alike is the paucity of special education personnel preparation programs that fully address the developmental characteristics of young children or adolescents (cf. Bursuck \& Epstein, 1986; Cline \& Billingsley, 1991; Zigmond \& Sansone, 1986). The scarcity of personnel preparation programs focusing on early intervention is understandable given the youth of the field. On the other hand, the scarcity of programs that prepare special educators to address the unique needs of adolescents is disheartening, given the fact that educators identified the need for developmentally appropriate practices with adolescents two decades ago.

\section{Transition Planning}

Although transitions occur throughout life, Congress acknowledged the special challenge of certain transitions by 
requiring formal transition planning for families with toddlers leaving Part $\mathrm{H}$ services for preschool, as well as for young adults with disabilities completing public education and entering the workforce or postsecondary education. Transition planning is intended to increase the individual's options to promote satisfactory relocation, provide for continuity in instruction and experience, and prepare the child/youth for successful entry into a new program.

Transition at ages 3 and 21 typically is an interagency event, and multiple agencies, as well as the family, are compelled by law to be involved in its planning and implementation (Rosenkoetter et al., 1994). At both the early childhood and secondary levels, transition planning is of two types: (a) community-wide discussions to develop general transition guidelines, programmatic needs, and resources, and (b) individual planning for specific students in transition.

With regard to early intervention, PL 99-457 required transition plans in the IFSP for each child anticipating leaving Part $\mathrm{H}$ for preschool services or "graduating" from special services. Steps required include:

- discussions with, and training of, parents regarding future placement and other transition-related matters, such as the IEP process and parental rights in special education.

- procedures to prepare the child for changes in service delivery, including steps to help the child adjust to, and function in, the new setting.

- with parental consent, the transmission of information about the child to the local education agency to ensure continuity of services, including evaluation and assessment information and copies of IFSPs that have been developed and implemented.

The goal of these actions is to promote continuity for an individual child and the child's family (Rosenkoetter et al., 1994; Wolery, 1989).

A few years later PL 102-119 provided the systemic support for individual transition planning by requiring Part $\mathrm{H}$ agencies and the public schools to develop general procedures and timelines to:

-include families in transition planning.

- help families understand the process, explore options for new placements, and develop reasonable and individualized schedules for evaluation and placement in new services in a timely manner.

- determine when flexibility should be introduced into the transition system to meet individual needs (for example, when a child has a late spring or early fall birthday).

Most states have defined their early childhood transition practices further (Rosenkoetter et al., 1994), and some have expanded transition planning policies beyond the so-called age 3 transition to other milestone moves for young children with disabilities and their families (e.g., hospital to community services, transition to kindergarten) (Shotts, Rosenkoetter, Streufert, \& Rosenkoetter, in press).

Indeed, transition planning has recently been recommended for all children, not just those with special needs. Transition to kindergarten has been the target of influential organizations such as the U.S. Department of Education (1991), Head Start (Administration for Children and Families, 1987), the National Association of State Boards of Education (1988), and the National Association of Elementary School Principals (1990). The landmark 1987 statement on developmentally appropriate practice by the National Association for the Education of Young Children (Bredekamp, 1987) called for transition planning for all children birth through age 8 .

Wehman (1992) defined transition from school to adulthood as "the life changes, adjustments, and cumulative experiences that occur in the lives of young adults as they move from school environments to more independent living and work environments" (p. 5). Transition planning and services for students at the secondary school level were first mandated by PL 101-476, which indicated that transition statements must be included in the student's IEP no later than the student's 16th birthday, and by the 14th birthday or earlier when considered appropriate.

States have latitude in how they address age requirements and in the format they use for the transition plan. States can require that transition plans be developed for all students with disabilities by age 14 , or they can determine the age (up to a student's 16th birthday) at which transition planning should occur on the basis of the individual student's needs and capabilities. States can require that individual transition plans (ITPs) be developed as part of the IEP or that transition statements be included in the IEP.

PL 101-476 defines transition services in the following statement:

Transition services means a coordinated set of activities for a student, designed within an outcome oriented process, which promotes movement from school to postschool activities, including postsecondary education, vocational training, integrated employment, including supported employment, continuing adult 
education, adult services, independent living, or community participation. The coordinated set of activities shall be based upon the individual student's needs, taking into account the student's preferences and interests, and shall include instruction, community experiences, development, employment, and other postschool adult living objectives, and, when appropriate, acquisitions of daily living skills and functional vocational evaluation. (Section 602 (a))

This mandate explicitly identifies (a) the purpose of transition services as preparation for all aspects of adult life; (b) the scope of transition services as including all services that might be needed to achieve successful adult adjustment; (c) the focus of decision making as the individual student and his or her preferences and interests; and (d) the range of outcomes of transition planning and services as including full community participation. Moreover, the mandate states that transition services must be coordinated and implies that interagency involvement and service coordination must exist to promote successful transition outcomes.

As is the case at the early childhood level, recent initiatives suggest that transition planning may become the norm for all adolescents as they move from secondary education to adult services. If enacted, the proposed School-toWork Transition Act (USDOE \& USDOL, 1993) would require that transition plans be developed for all students by 11 th grade. The proposed legislation formally acknowledges the critical roles that individual planning and local and state coordination of services play in helping all adolescents achieve their individual goals and their potentials as productive, contributing members of communities and society at large.

\section{Expanding Definitions of Education}

Effective intervention with babies and young adults means that education must assume nontraditional roles and responsibilities, form new partnerships, and provide unfamiliar services in unfamiliar locations. As discussed, many agencies beyond the schools and multiple disciplines besides education are likely to be involved in delivering both early intervention and secondary transition services.

Congress made a prescient semantic choice in selecting the term early intervention, rather than special education, to describe services for infants and toddlers who have or are at risk for disabilities. The chosen nomenclature acknowledges that intervention may consist of a diversity of activities, delivered or supervised by family members or specialists from as many as 16 disciplines, but coordinated for the single purpose of promoting the child's maximum development.

The complexities of delivering services to very young children necessitate some degree of transdisciplinary functioning among service providers and family members. As a result, at any one time the "early interventionist" might be a nurse, a child care provider, a physical therapist, a special educator, or a grandmother. The lead agency charged with coordinating services at the state or local level may just as well be a health or social service agency as an education agency (OSEP, 1993). The services themselves are unlikely to be delivered in a school building.

Likewise, secondary education, transition, and adult services for adolescents and young adults with disabilities also involve home and community placements, a variety of activities foreign to traditional education, delivery and supervision of services by a variety of disciplinary specialists, and coordination of events to support an adolescent or young adult in achieving maximum independence, social interaction, and productivity. Family members, job coaches, special educators, secondary school counselors, vocational counselors, employers, co-workers, health professionals, and transition specialists may each provide critical components of a student's experience. As with early intervention, communities vary in the services and array of professional roles they typically provide; thus, transdisciplinary approaches may be essential to ensure that the young adult has the necessary opportunities for learning essential skills (Orelove \& Sobsey, 1991).

At both levels, intervention is "educational" in terms of promoting acquisition of new skills or capacities. When applied in this context, however, the term education must stretch beyond its typical meaning in terms of curriculum, instruction, and delivery systems. Likewise, the roles of "teacher" are functionally expanded by the need to deliver services typically assigned to other specialists. As examples, a special educator might work with an infant and mother to prompt chewing responses, and another teacher might coach an adolescent in assembling computer memory boards in a factory setting or show a co-worker how to prompt a particular response.

These expansions of both the definition of education and the functional roles of educators are important to the realization of comprehensive services for the students involved and their families. At each age level comprehensive services involve varied roles for educators and integration of education with daily routines, which, in effect, supersede the traditional structures, functions, and practices of most existing elementary and secondary schools. 


\section{Provision of Services in Natural Environments}

As discussed, quality services for infants and toddlers, as well as for adolescents and young adults, necessitate an expanded concept of education. Perhaps the most concrete evidence of how education must be expanded for all children lies in the location of services for young children and adolescents with special needs.

Although the concept of natural environments takes on different meanings at the two age groups under discussion, in either case schools are not likely to be the most natural or the most efficacious of environments. Part $\mathrm{H}$ of IDEA calls for services to infants and toddlers in "natural environments, including the home and community settings in which children without disabilities participate" (Section 303.12 (b)). For children younger than age 4, home-based services, child care services, preschool, or Head Start are natural environments, whereas schools are not, because agemates without disabilities are usually not served in schools.

The National Early Childhood Technical Assistance System stresses that the concept of natural environments includes integrating the child into the family and all of its normal activities. Integration into the family's cultural system and community might involve assisting the family to include the child in all of the activities in which the family normally engages, including religious, sports, and recreational activities. Thus, if the family's recreational interests focus on motorcycles, the early interventionist would assist the family and the target culture to make accommodations so the child and family can participate as others do in this environment (NEC*TAS, 1988).

In a natural environment an early interventionist can model for the parent, child care provider, or other significant adult effective techniques to foster child development. Subsequently, the adult in that setting can deliver appropriate intervention throughout the routines of the day at times when the young child is physiologically and psychologically available for interaction.

The principle of natural environments likewise extends to the assessment process. Recommended practice centers on ecological assessment procedures in which the child's functioning is observed and evaluated in each of the contexts that constitute the child's natural environment (Benner, 1992; Meisels \& Provence, 1989; Westby, 1986). Family members and other traditional caregivers, rather than a psychologist or other professional diagnostician, are likely to be the interactors during this assessment.

For adolescents, the concept of natural environments focuses on participation in the community where they will ultimately need to apply targeted skills (Sailor et al., 1989; Turnbull et al., 1993; Wehman, 1992). Likewise, recommended practices for assessment of adolescent functioning include observing and assessing the student in the variety of employment, residential, and social settings and tasks relevant to his or her community adjustment (Stodden, Ianacone, Boone, \& Bisconer, 1987).

For all adolescents, schools have traditionally been the settings where students are most apt to have contact with age peers. Nevertheless, based on findings that adolescents and adults with disabilities have high dropout rates, low employment rates, and poor integration into community settings (cf. Edgar, 1987; Edgar \& Levine, 1987; Halpern \& Benz, 1987; Hasazi, Gordon, \& Roe, 1985; Zigmond \& Thorton, 1985), many have recommended a major shift in curriculum, with emphasis on instruction in community environments for secondary school students with mild disabilities (cf. Affleck, Edgar, Levine, \& Koetering, 1990; Chadsey-Rusch, Rusch, \& O'Reilly, 1991; Siegel, 1988) as well as those with severe disabilities (Brown et al., 1983; Brown et al., 1991).

These recommendations are consistent with recommended or developmentally appropriate practices described above; however, Clark and Mellard (1992) pointed out that community-based instruction can increase the separation of adolescents in special education from their peers in general education. The potential dilemma Clark and Mellard identified may not be realized, however. Recently, policy makers have concluded that the dropout rates and low attendance rates for adolescents in general suggest that schools are failing to provide appropriate education to many students, not just those with disabilities (Wehman, 1992).

The proposed School-to-Work Transition Act (USDOE \& USDOL, 1993) suggests that educators, persons in business, and politicians are struggling to expand the definition of education for all students at the secondary level. This act would provide youth with a full array of services and experiences, including continued academics, community-based education with paid work experiences, apprenticeships, and instruction in community living skills. Thus, recommended practices in special education may become the model for developmentally appropriate practice for all adolescents. The emergence of educational services for all students reaffirms the validity of the community as one among several natural environments for adolescents and young adults.

For young children and young adults, the principle of natural environments affects system planners in two sig- 
nificant ways. First, it challenges service delivery systems to provide a variety of program options for individuals with disabilities similar to those available to people without disabilities. Second, it prompts planners to seek interventions that are effective and efficient without being intrusive (Rosenkoetter et al., 1994).

\section{DIFFERENCES IN SERVICES}

Several differences between early intervention and secondary education/transition to adulthood services warrant exploration. First, services across agencies at the early intervention level are emerging in most parts of the nation. The relative youth of early intervention services may provide incentives for effective collaboration as a wide variety of service providers are faced with quickly developing service systems where none existed before. In contrast, secondary-level special education services and many parts of the adult service system have been in place but may have a lengthy history of noncollaboration. As a result, different professional cultures with unique languages describing disabilities and services, different eligibility systems, and different assessment and program planning requirements have developed. These separate histories of adolescent and adult service systems pose potential problems because of the tendency of established bureaucracies to engage in selfpreservation by perpetuating distinctive professional cultures (Skrtic, 1991). Johnson, Bruininks, and Thurlow (1987) verify that service fragmentation often exists because of barriers at state and local levels even when interagency agreements have been forged.

A second difference relates to public attitudes surrounding the two levels of service. Taxpayers and policy makers tend to view services to infants and toddlers optimistically as prevention activities with the potential for future savings. To an uninformed public, secondary special education and adult services for individuals with disabilities may be viewed as indications that prevention or remediation has failed. Thus, services at these levels may face greater difficulty attracting financial support, volunteer time commitments, and broad-based public enthusiasm. These limitations may be significant barriers to program development at the secondary level. Finally, even though early intervention and secondary transition services have many similarities, tensions may arise between their advocates as they compete with one another for scarce resources.

\section{CONCLUSIONS}

Recommended practices in terms of organization of services for early intervention and secondary education/transition share similar implementation structures. At the structural level services at both age ranges feature horizontal decision making that promotes system change, community-referenced services, consumer responsiveness, and service coordination. These elements constitute a new paradigm for delivery of education and the full array of social services necessary for participation in education: school-linked services integration. By design the structures for both early intervention and secondary/transition services have been organized in a manner that acknowledges that students with special needs at these age ranges need more complex, comprehensive, and interrelated services than the services traditionally associated with education.

This article has argued that best practice at both the early intervention and the secondary/transition levels might be characterized by the concept of developmentally appropriate practice, which involves addressing the developmental needs of young children and adolescents in planning services, recognizing the needs and contributions of families at each age range, incorporating transition services as central to successful intervention, and acknowledging that services may best be delivered in settings other than those traditionally associated with education. Moreover, education is a relevant player in services at each level only to the extent that our definitions of education are expanded beyond the traditional structures, roles, and functions of schools.

Given the adhocratic structures of early intervention and secondary/transition, system change is likely to widen beyond these two levels. For example, service coordination, a developmental approach to instruction, transition planning, instruction in natural environments, and greater responsiveness to family and community values are likely to influence other levels of education and social service as well and, thus, to affect community supports for children and youth without identified disabilities. Moreover, expanding family skills for advocacy as a result of participation in effective early intervention and secondary education/transition planning systems are likely to fuel changes in schoolbased elementary special education as well as adult services for people with disabilities. 


\section{RECOMMENDATIONS}

The existing commonalities between early intervention services and secondary transition services for students with disabilities argue for mutual awareness among service providers of the commonalities in contexts, learnings, and recommended practices. Personnel from each level can make significant contributions to the development of the other. Accordingly, we recommend that those responsible for implementing systems at each level:

1. Bring together community personnel in early intervention and secondary transition to discuss each collaborative system and the procedures that sustain it.

2. Conduct joint training on skills needed at both levels: transition planning, service coordination/case management, transdisciplinary teaming, strategies for familycentered intervention, ecological assessment, and knowledge of multiple service agencies.

3. Jointly identify barriers to horizontal service collaboration at the community level and develop action plans to overcome them.

4. Write interagency agreements and timelines across age levels to ensure the timely and ongoing participation of community agencies in service delivery and transition planning.

5. Use emergent school-linked service integration efforts for young children and adolescents to promote systems change toward full-scale development of school-linked services for all students and their families.

6. Share relevant research literature across age levels, including dissemination of models for horizontal, consumer-centered, community-based service provision.

7. Advocate for radical change in personnel preparation to reflect the changes in traditional educational (and special educational) practices at these two levels to accomplish desired outcomes.

8. Include discussion of commonalities in structure and practice across the two levels in personnel preparation programs at the preservice and inservice levels.

9. Promote continuity in instruction and services across ages for all children by linking improved transition planning for toddlers and adolescents with disabilities to interagency efforts for all children in the community.

With communication and joint problem solving across age levels, community planners, including families, can take the hard-won learnings from one age level and apply them to others.

\section{REFERENCES}

Administration for Children and Families. (1987). Transition. Washington, DC: U.S. Department of Health and Human Services, Head Start Bureau.

Affleck, J. Q., Edgar, E., Levine, P., \& Koetering, L. (1990). Postschool status of students classified as mildly mentally retarded, learning disabled, or nonhandicapped: Does it get better with time? Education and Training in Mental Retardation, 25, 315-324.

Agosta, J. (1989). Using cash assistance to support family efforts. In G. H. S. Singer \& L. K. Irwin (Eds.), Support for caregiving families: Enabling positive adaption to disability (pp. 189-204). Baltimore: Paul H. Brookes.

Alley, G., \& Deshler, D. D. (1979). Teaching the learning disabled adolescent: Strategies and methods. Denver: Love.

Bailey, D. B. (1989). Case management in early intervention. Journal of Early Intervention, 13, 120-134.

Ballard, J., Ramirez, B., \& Zantal-Wiener, K. (1987). Public Law 94-142, Section 504, and Public Law 99-457: Understanding what they are and are not. Reston, VA: Council for Exceptional Children.

Bates, M. (1990). Best practices in transition planning: Quality indicators. Carbondale: Southern Illinois University, Illinois Transition Project.

Benner, S. M. (1992). Assessing young children with special needs: An ecological perspective. White Plains, NY: Longman Publishing Group.

Benz, M., \& Halpern, A. (1987). Transition services for secondary students with mild disabilities: A statewide perspective. Exceptional Children, 53(6), 507-514.

Bredekamp, S. (1987). Developmentally appropriate practice in early childhood programs serving children from birth through age 8. Washington, DC: National Association for the Education of Young Children.

Bredekamp, S., \& Rosegrant, T. (Eds.). (1992). Reaching potentials: Appropriate curriculum and assessment for young children (Vol. 1). Washington, DC: National Association for the Education of Young Children.

Bricker, D., \& Cripe, J. W. (1992). An activity-based approach to early intervention. Baltimore: Paul H. Brookes.

Brotherson, M. J., Berdine, W. H., \& Sartini, V. (1993). Transition to adult services: Support for ongoing parent participation. Remedial and Special Education, 14(4), 44-51.

Brown, L., Branston, M. B., Hamre-Nietupski, A., Pumpian, I., Certo, N., \& Gruenewald, L. (1979). A strategy for developing chronological age-appropriate and functional curricular content for severely handicapped adolescents and young adults. Journal of Special Education, 13, 81-90.

Brown, L., Nisbet, J., Ford, A., Sweet, M., Shiraga, B., York, J., \& Loomis, R. (1983). The critical need for nonschool instruction in educational programs for severely handicapped students. Journal of the Association for Persons with Severe Handicaps, 8, 71-77. 
Brown, L., Schwarz, P., Udvari-Solner, A., Kampschroer, E. F., Johnson, F., Jorgensen, J., \& Gruenewald, L. (1991). How much time should students with severe intellectual disabilities spend in regular education classrooms and elsewhere? Journal of the Association for Persons with Severe Handicaps, 16, 39-47.

Bursuck, W. D., \& Epstein, M. H. (1986). A survey of training programs for teachers of mildly handicapped adolescents. Teacher Education and Special Education, 9(1), 3-8.

Carta, J. J., Schwartz, I. S., Atwater, J. B., \& McConnell, S. R. (1991). Developmentally appropriate practice: Appraising its usefulness for young children. Topics in Early Childhood Special Education, 1(1), 1-20.

Chadsey-Rusch, J., Rusch, F. R., \& O'Reilly, M. F. (1991). Transition from school to integrated communities. Remedial and Special Education, 12(6), 23-33.

Clark, G. M., \& Kolstoe, O. P. (1990). Career development and transition education for adolescents with disabilities. Boston: Allyn \& Bacon.

Clark, G. M., \& Mellard, D. E. (1992). National high school project: Vol. 2. A quantitative description of concepts and practices for students with disabilities. Lawrence: University of Kansas.

Cline, B. V., \& Billingsley, B. S. (1991). Teachers' and supervisors' perceptions of secondary learning disabilities programs: A multi-state survey. Learning Disabilities Research and Practice, 6, 158-165.

D'Alazo, B., \& Wiseman, D. (1978). Actual and desired roles of the high school learning disability resource room teacher. Journal of Learning Disabilities, 11, 390-397.

Deshler, D. D., \& Schumaker, J. B. (1986). Learning strategies: An alternative for low-achieving adolescents. Exceptional Children, 52, 583-590.

Division for Early Childhood. (1993). Recommended practices of quality in programs for infants and young children with special needs and their families. Reston, VA: Division for Early Childhood.

Dunst, C. J., Trivette, C. M., \& Deal, A. (1988). Enabling and empowering families: Principles and guidelines for practice. Cambridge, MA: Brookline Books.

Edgar, E. (1987). Secondary programs in special education: Are many of them justifiable? Exceptional Children, 53(6), 555561.

Edgar, E., \& Levine, P. (1987). Special education students in transition: Washington state data 1976-1987: Students in transition. Unpublished manuscript.

Goodman, J. F. (1992). When slow is fast enough. New York: Guilford Press.

Halpern, A. S. (1987). Characteristics of a quality program. In C. L. Warger \& B. B. Weiner (Eds.), Secondary special education. Reston, VA: Council for Exceptional Children.

Halpern, A. S., \& Benz, M. R. (1987). A statewide examination of secondary special education for students with mild disabilities: Implications for the high school curriculum. Excep- tional Children, 53(6), 507-514.

Halpern, A. S., Benz, M. R., \& Lindstrom, L. (1991). A systems change approach to improving secondary special education and transition programs at the local community level. Unpublished manuscript, University of Oregon, Eugene.

Hanson, M. J., \& Lynch, E. W. (1989). Early intervention: Implementing child and family services for infants and toddlers who are at-risk or disabled. Austin, TX: Pro-Ed.

Hardman, M., \& McDonnell, J. (1987). Implementing federal transition initiatives for youths with severe handicaps: The Utah community-based transition project. Exceptional Children, 53(6), 493-498.

Hasazi, S. B., Gordon, L. R., \& Roe, C. A. (1985). Factors associated with the employment status of handicapped youth exiting high school from 1979 to 1983. Exceptional Children, 51, 455-469.

Hazel, R., Barber, P. A., Roberts, S., Behr, S. K., Helmstetter, E., \& Guess, D. (1988). A community approach to an integrated service system for children with special needs. Baltimore: Paul H. Brookes.

Hobbs, N., Dokecki, P. R., Hoover-Dempsey, K. V., Moroney, R. M., Shayne, M. W., \& Weeks, K. H. (1984). Strengthening families. San Francisco: Jossey-Bass.

Johnson, D. R., Bruininks, R. H., \& Thurlow, M. L. (1987). Meeting the challenge of transition service planning through interagency cooperation. Exceptional Children, 53(6), 522530.

Kagan, S. L. (1991). United we stand: Collaboration for child care and early education services. New York: Teachers College Press.

Kanter, R. (1983). The change masters. New York: Simon \& Schuster.

Kiernan, W. E., \& Ciborowski, J. (1986). Survey of employment for adults with developmental disabilities. Remedial and Special Education, 7, 25-30.

Kirst, M. W., \& McLaughlin, M. (1990). Rethinking policy for children: Implications for educational administration. In D. Mitchell \& L. L. Cunningham (Eds.), Educational Leadership in changing contexts of families, communities, and schools. 89th Yearbook of the National Society for the Study of Education (Part II) (pp. 69-90). Chicago: University of Chicago Press.

Kohler, P. (1993). Best practices in transition: Substantiated or implied? In P. D. Kohler, J. R. Johnson, J. Chadsey-Rusch, \& F. R. Rusch (Eds.), Transition from school to adult life: Foundations, best practices, and research directions. UrbanaChampaign: University of Illinois, Transition Research Institute at Illinois.

Kokaska, C., \& Brolin, D. (1983). Career education for handicapped individuals. Columbus, $\mathrm{OH}$ : Charles E. Merrill.

Lynch, E. W., \& Hanson, M. J. (Eds.). (1992). Developing crosscultural competence: A guide for working with young children and their families. Baltimore: Paul H. Brookes.

Lynch, E. W., \& Stein, R. (1982). Perspectives on parent partici- 
pation in special education. Exceptional Education Quarterly, $3(2), 56-63$.

Mahoney, G., Robinson, C., \& Powell, A. (1992). Developmentally appropriate practices. Topics in Early Childhood Special Education, 12(1), 105-120.

McGonigel, M. J., Kaufmann, R. K., \& Johnson, B. H. (Eds.). (1991). Guidelines and recommended practices for the individualized family service plan (2nd ed.). Bethesda, MD: Association for the Care of Children's Health.

Meisels, S. J., \& Provence, S. (1989). Screening and assessment: Guidelines for identifying young disabled and developmentally vulnerable children and their families. Washington, DC: National Center for Clinical Infant Programs.

Melaville, A. I., \& Blank, M. J. (1993). Together we can: A guide for crafting a profamily system of education and human services. Washington, DC: U.S. Department of Education and U.S. Department of Health and Human Services.

Miller, L. J., Strain, P. S., McKinley, J., Heckathorn, K., \& Miller, S. (1993). Preschool placement decisions: Are they predictors of future placement? Pittsburgh: St. Peter's Child Development Centers, Research Institute on Preschool Mainstreaming.

Mithaug, D. E., Martin, J. E., \& Agran, M. (1987). Adaptability instruction: The goal of transitional programming. Exceptional Children, 53(6), 500-505.

NAEYC \& NAECS/SDE. (1992). Guidelines for appropriate curriculum content and assessment in programs serving children ages 3 through 8 . In S. Bredekamp \& T. Rosegrant (Eds.), Reaching potentials: Appropriate curriculum and assessment for young children (Vol. 1, pp. 92-113). Washington, DC: National Association for the Education of Young Children.

National Association of Elementary School Principals. (1990), Early childhood education and the elementary school principal: Standards for quality programs for young children. Alexandria, VA: Author.

National Association of State Boards of Education. (1988). Right from the start: The report of the NASBE task force on early childhood education. Alexandria, VA: Author.

National Association of State Boards of Education. (1991). Caring communities: Supporting young children and families. Alexandria, VA: Author.

National Early Childhood Technical Assistance System. (1988). The concept of least restrictive environment as it applies to infants and toddlers. Chapel Hill, NC: NEC*TAS.

Office of Special Education Programs. (1993). Fifteenth annual report to Congress. Washington, DC: U.S. Department of Education.

Orelove, F. P., \& Sobsey, D. (1991). Educating children with multiple disabilities: A transdisciplinary approach. Baltimore: Paul H. Brookes.

Peck, C. A., Odom, S. A., \& Bricker, D. D. (Eds.). (1993). Integrating young children with disabilities into community programs: Ecological perspectives on research and implementation. Baltimore: Paul H. Brookes.
Raver, S. A. (1991). Strategies for teaching at-risk and handicapped infants and toddlers. New York: Merrill/Macmillan.

Rojewski, J. W. (1992). Key components of model transition services for students with learning disabilities. Learning Disabilities Quarterly, 15, 135-150.

Rosenkoetter, S. E., Hains, A. H., \& Fowler, S. A. (1994). Bridging early services for children with special needs: $A$ practical guide to transition planning. Baltimore: Paul $\mathrm{H}$. Brookes.

Sailor, W. (1991). Special education in the restructured school. Remedial and Special Education, 12(6), 8-22.

Sailor, W., Anderson, J. L., Halvorsen, A. T., Doering, K., Filler, J., \& Goetz, L. (1989). The comprehensive local school: Regular education for all students with disabilities. Baltimore: Paul H. Brookes.

Sailor, W., Gerry, M., \& Wilson, W. C. (1993). Policy implications of emergent full inclusion models for the education of students with severe disabilities. In M. Wang, H. Walberg, \& M. Reynolds (Eds.), The handbook of special education (Vol. IV). Oxford, England: Pergamon Press.

Schalock, R. L. (1985). Comprehensive community services: A plea for interagency collaboration. In R. H. Bruininks \& K. C. Lakin (Eds.), Living and learning in the least restrictive environment (pp. 37-64). Baltimore: Paul H. Brookes.

Shotts, C. K., Rosenkoetter, S. E., Streufert, C. A., \& Rosenkoetter, L. I. (in press). Transition policies and issues: A view from the states. Topics in Early Childhood Special Education.

Siegel, S. (1988). The career ladder program: Implementing ReED principles in vocational settings. Behavioral Disorders, $14,16-26$.

Simeonsson, R., \& Bailey, D. B. (1990). Family dimensions in early intervention. In S. J. Meisels \& J. P. Shonkoff (Eds.), Handbook of early childhood intervention (pp. 428-444). New York: Cambridge University Press.

Skrtic, T. M. (1991). Behind special education: A critical analysis of professional culture and school organization. Denver: Love.

Stodden, R. A., Ianacone, R. N., Boone, R. M., \& Bisconer, S. W. (1987). Curriculum-based vocational assessment: A guide for assessing youth with special needs. Honolulu: Centre Publications.

Sugarman, J. M. (1991). Building early childhood systems: A resource handbook. Washington, DC: Child Welfare League of America.

Swan, W. W., \& Morgan, J. L. (1993). Collaborating for comprehensive services for young children and their families. Baltimore: Paul H. Brookes.

Trohanis, P. L. (1989). An introduction to PL 99-457 and the national policy agenda for serving young children with special needs and their families. In J. J. Gallagher, P. L. Trohanis, \& R. M. Clifford (Eds.), Policy implementation and PL 99-457: Planning for young children with special needs (pp. 1-18). Baltimore: Paul H. Brookes.

Turnbull, H. R., Bateman, D. F., \& Turnbull, A. P. (1993). Fam- 
ily empowerment. In P. Wehman (Ed.), The ADA mandate for social change (pp. 157-173). Baltimore: Paul H. Brookes.

Turnbull, H. R., Turnbull, A. P., Bronicki, G. J., Summers, J. A., \& Roeder-Gordon, C. (1989). Disability and the family: A guide to decisions for adulthood. Baltimore: Paul H. Brookes.

U.S. Department of Education. (1991). Preparing young children for success: Guideposts for achieving our first national goal. Washington, DC: U.S. Government Printing Office.

U.S. Department of Education \& U.S. Department of Labor. (1993). The school-to-work transition act of 1993.

U.S. General Accounting Office. (1992). Integrating human services: Linking at-risk families with services more successful than system reform efforts (Report No. GAO/HRD-92108). Washington, DC: Government Printing Office.

Wehman, P. (1992). Transition for young people with disabilities. Challenges for the 1990s. Education and Training in Mental Retardation, 27(2), 112-118.

Weick, K. (1976). Educational organizations as loosely coupled systems. Administrative Science Quarterly, 21, 1-18.

Weick, K. (1979). The social psychology of organizing. New York: Random House.

Westby, C. E. (1986). Cultural differences in caregiver-child interaction: Implications for assessment and intervention. In L. Cole \& V. Deal (Eds.), Communication disorders in multicultural populations. Rockville, MD: American Speech and Hearing Association.

Widerstrom, A. (1991). Developmentally appropriate practice and early childhood special education. Workshop presented at International Conference on Children with Special Needs, St. Louis, MO.
Will, M. (1984). Bridges from school to working life: OSERS programming for the transition of youth with disabilities. Washington, DC: U.S. Department of Education, Office of Special Education and Rehabilitative Services.

Wolery, M. (1989). Transition in early childhood special education: Issues and practices. Focus on Exceptional Children, 22(2), 1-16.

Wolery, M., Strain, P. S., \& Bailey, D. B. (1992). Reaching potentials for children with special needs. In S. Bredekamp \& T. Rosegrant (Eds.), Reaching potentials: Appropriate curriculum and assessment for young children (Vol. 1, pp. 92-113). Washington, DC: National Association for the Education of Young Children.

Wolfensberger, W. (1972). Principles of normalization. Toronto, Ontario: National Institute of Mental Retardation.

Zigmond, N., \& Sansone, J. (1986). Designing a program for the learning disabled adolescent. Remedial and Special Education, 7, 25-30.

Zigmond, N., Silverman, R., \& Laurie, T. (1978). Competencies for teachers. In L. Mann, L. Goodman, \& J. L. Wiederholt (Eds.), Teaching the learning disabled adolescent. Boston: Houghton Mifflin.

Zigmond, N., \& Thorton, H. (1985). Learning disabled graduates and dropouts. Learning Disabilities Quarterly, 1(1), 50-55.

Zipper, I. N., Hinton, C., Weil, M., \& Rounds, M. (1993). Service coordination for early intervention: Parents and professionals. Cambridge, MA: Brookline Books.

Work on this article was supported, in part, by grant \#H024D30046 from the U.S. Department of Education to the Associated Colleges of Central Kansas.

PERMISSIONS AND COPYRIGHT - All rights are reserved. No part of this publication may be reproduced, photocopied, faxed, stored in a retrieval system, or transmitted, in any form or by any means, electronic, mechanical, recording or otherwise, without the prior written permission of the publisher. $\bullet$ Back issues are available for sale. $\bullet$ Reproduction requires permission and payment of fees. It is illegal and a violation of federal copyright law to reproduce this publication without permission. Direct all inquiries to the permissions editor. 


\section{NANCY J. BONSANGUE SUSANNE G. FLATLEY}

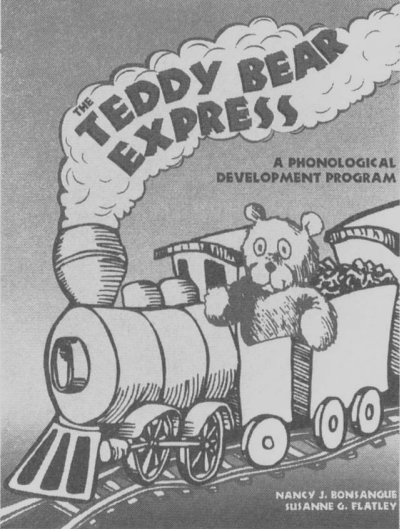

The Teddy Bear Express! addresses the phonological development of young children. All the materials were developed with parental involvement in mind. Although parental involvement in weekly sessions with the speech/language pathologist is strongly encouraged, it is not essential, providing parents are given guidance and are committed to completing the home activities.

Each lesson focuses on a particular phonological process. Lessons are written for a small group of children (approximately five or six) but can be adapted for use in a classroom setting. Lessons can also be adapted for sessions with individual children. All lessons have been developed with regard to a young child's interest and natural environment.

Sharing, music, and literature are activities that help reinforce the targeted concept. Sharing is encouraged to foster speech production practice and interaction. Songs and stories are chosen based on familiarity and appeal to young children, as well as how effectively they rein- force a particular concept. Included in each lesson are suggestions for songs and stories. A word list is also included in each lesson for auditory stimulation. It is read and then sent home to be read by the parent daily. All the words on the word list contain the phoneme that was used to present the phonological process during that session.

The program is particularly suited for young children in Head Start, regular education preschool, kindergarten, and firstgrade classrooms to reinforce their communication skills.

9308/paperback/ISBN 0-89108-232-8

$\$ 24.95$

\section{ORDER FORM .... Yes!' I want to order The Teddy Bear Express!}

Mail to:

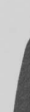

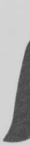

LOVE

PUBLISHING

COMPANY

1777 South Bellaire Street

Denver, Colorado 80222

$\square$ Check enclosed

$\square$ Purchase order

Charge: $\begin{aligned} \square & \text { Visa } \\ \square & \text { Mastercard }\end{aligned}$

Please send copies TODAY.

List Price:

$\$ 24.95$

Shipping and Handling:

2.00

Name

Address

City State Zip

Telephone

Name on Card

Account \# Expires 


\section{Professional Update}

\section{September 30, October 1-2, 1994}

International Conference on Mental Retardation and Developmental Disabilities

Woodfield Hilton Hotel

Arlington Heights, Illinois

Contact: Larry Sargent

515-265-5301

or

Iris Kerbis Puccini

708-933-8863

\section{November 8-10, 1994}

TASH Conference

Atlanta Marriott Marquis Hotel

Atlanta, Georgia

Contact: Robin Tincha

800-482-TASH

\section{November 2-5, 1994}

Canadian Council for Exceptional Children 1994 Congress

Palliser Hotel

Calgary, Alberta, Canada

Contact: Robert St. Onge

403-467-8896

Fax: 403-467-5469

\section{- November 10-12, 1994}

Council for Learning Disabilities

Town and Country Hotel

San Diego, California

Contact: Kirsten McBride

913-492-8755

Fax: 913-492-2546 